\title{
Increase in Alphaproteobacteria in association with a polychaete, Capitella sp. I, in the organically enriched sediment
}

\author{
Tadao Kunihiro ${ }^{1,4}$, Hiroyuki Takasu ${ }^{1,5}$, Tomoaki Miyazaki ${ }^{1}$, Yuuta Uramoto ${ }^{1}$, \\ Kyoko Kinoshita ${ }^{1}$, Supaporn Yodnarasri ${ }^{1}$, Daigo Hama ${ }^{2}$, Minoru Wada ${ }^{3}$, Kazuhiro Kogure ${ }^{3}$, \\ Kouichi Ohwada $^{1}$ and Hiroaki Tsutsumi ${ }^{1}$ \\ ${ }^{1}$ Faculty of Environmental and Symbiotic Sciences, Prefectural University of Kumamoto, Kumamoto, Japan; \\ ${ }^{2}$ Keiten Co., Ltd., Kusuura, Amakusa, Kumamoto, Japan and ${ }^{3}$ Ocean Research Institute, The University \\ of Tokyo, Nakano, Tokyo, Japan
}

\begin{abstract}
We conducted bioremediation experiments on the organically enriched sediment on the sea floor just below a fish farm, introducing artificially mass-cultured colonies of deposit-feeding polychaete, Capitella sp. I. To clarify the association between the Capitella and bacteria on the efficient decomposition of the organic matter in the sediment in the experiments, we tried to identify the bacteria that increased in the microbial community in the sediment with dense patches of the Capitella. The relationship between TOC and quinone content of the sediment as an indicator of the bacterial abundance was not clear, while a significant positive correlation was found between Capitella biomass and quinone content of the sediment. In particular, ubiquinone-10, which is present in members of the class Alphaproteobacteria, increased in the sediment with dense patches of the Capitella. We performed denaturing gradient gel electrophoresis (DGGE) analyses to identify the alphaproteobacterial species in the sediment with dense patches of the worm, using two DGGE fragments obtained from the sediment samples and one fragment from the worm body. The sequences of these DGGE fragments were closely related to the specific members of the Roseobacter clade. In the associated system with the Capitella and the bacteria in the organically enriched sediment, the decomposition of the organic matter may proceed rapidly. It is very likely that the Capitella works as a promoter of bacteria in the organically enriched sediment, and feeds the increased bacteria as one of the main foods, while the bacteria decompose the organic matter in the sediment with the assistance of the Capitella.
\end{abstract}

The ISME Journal (2011) 5, 1818-1831; doi:10.1038/ismej.2011.57; published online 5 May 2011

Subject Category: microbial ecology and functional diversity of natural habitats

Keywords: Alphaproteobacteria; Roseobacter clade; Capitella sp. I; bioturbation; quinone; organic loading

\section{Introduction}

On the sea floor with muddy sediment, depositfeeding animals tend to dominate in the benthic community (Sanders, 1958; Levinton, 1972; Lopez and Levinton, 1987). They move actively on the sediment surface or burrow into its subsurface layers, feeding and excreting the sedimentary organic and inorganic materials (Fauchald and Jumars, 1979; Lopez and Levinton, 1987). These

Correspondence: T Kunihiro, Center for Marine Environmental Studies (CMES), Ehime University, 2-5 Bunkyo-cho, Matsuyama, Ehime 790-8577, Japan.

E-mail: kunihiro@ehime-u.ac.jp or tadao92@mwa.biglobe.ne.jp ${ }^{4}$ Current address: Center for Marine Environmental Studies (CMES), Ehime University, 2-5 Bunkyo-cho, Matsuyama, Ehime 790-8577, Japan.

${ }^{5}$ Current address: Center for Ecological Research, Kyoto University, 2-509-3 Hirano, Otsu, Shiga 520-2113, Japan.

Received 7 October 2010; revised 10 February 2011; accepted 16 March 2011; published online 5 May 2011 biological activities have an enormous impact, not only on the reworking of the sediment, but also on the abundance and community structure of microorganisms in the sediment (Dobbs and Guckert, 1988; Steward et al., 1996; Marinelli et al., 2002; Lucas et al., 2003; Papaspyrou et al., 2006). Microbial abundance tends to increase along the inner walls of the burrows (Alongi, 1985; Aller and Aller, 1986; Lucas et al., 2003; Wu et al., 2003; Wada et al., 2006) and around the feces excreted from the animals (Hargrave, 1976; Plante and Wilde, 2001). Various bacteria actively facilitate the decomposition of the organic matter at these sites (Aller et al., 1983; Reichardt, 1988).

Bacteria in the sediment react immediately to fresh and labile organic matter deposited on the sediment (Meyer-Reil, 1983; Gooday and Turley, 1990). Excessive loading of organic matter on the sediment tends to consume an increasing amount of dissolved oxygen in the overlying and interstitial 
water of the sediment, and results in oxygen depletion in the bottom water (Pearson and Rosenberg, 1978; Holmer and Kristensen, 1992). As a result, anaerobic decomposition of the organic matter by sulfate-reducing bacteria often follows production of high levels of hydrogen sulfide in the sediment (Holmer and Kristensen, 1992). As the organic enrichment of the sediment increases, it restricts the occurrence of macro-benthic animals due to the development of reduced conditions. In heavily organically enriched sediments, exclusively several species of deposit-feeding thread-like small polychaetes, such as Capitella species and spionids occur exclusively, monopolizing the food resources contained in the sediment (Grassle and Grassle, 1976; Tsutsumi and Kikuchi, 1983; Tsutsumi, 1987, 1990). Therefore, organically enriched sediment appears to be one of the most suitable sites for observing the interaction and association between the deposit-feeding polychaetes and bacteria.

Fish farming has developed in enclosed coastal seas throughout the world since the 1980s (FAO, 1992). However, nowadays, enormous quantities of fish feces and food residues have deposited on the sea floors just below the net pens in many of the fish farms. They are suffering from the deterioration of water quality, due to accelerated consumption of dissolved oxygen from the organically enriched sediment (Gowen and Bradbury, 1987; Wu, 1995; Naylor et al., 2000; Buschmann et al., 2006). On the other hand, to reveal the interaction and association between the deposit-feeding polychaetes and bacteria, the sea floors just below the net pens in the fish farms provide one of the most ideal and accessible sites. There, the Capitella species tend to predominate in the macro-benthic communities (Tsutsumi, 1987, 1995; Weston, 1990; Karakassis and Hatziyanni, 2000; Macleod et al., 2007). Tsutsumi and Montani (1993) focused on the rapid increase of Capitella species in the organically enriched sediment just below the fish farm during the cold seasons with dissolved oxygen-rich conditions, and its impact on the decomposition of organic matter in the sediment. They proposed a bioremediation technique to treat the organically enriched sediment that placed artificially mass-cultured colonies of Capitella sp. I on it in autumn, when dissolved oxygen conditions of the bottom water had recovered.

Based on this idea mentioned above, we have conducted bioremediation experiments to treat the organically enriched sediment deposited just below a fish farm in Amakusa, Kyushu, Western Japan, between 2003 and 2006, introducing the artificially mass-cultured colonies of Capitella sp. I on the sea floor in autumn. In the bioremediation experiments, the introduced Capitella colonies increased explosively on the organically enriched sediment during the late autumn and winter, and the amount of sedimentary organic matter decreased significantly following the rapid population growth (Tsutsumi et al., 2005a; Kinoshita et al., 2008). Kunihiro et al. (2008) found a significant positive correlation between Capitella biomass and the quinone content of the sediment as an indicator of the biomass of microorganisms (Saitou et al., 1999; Hiraishi et al., 2003), and a marked increase of ubiquinone-10 (UQ-10) among the quinones when dense patches of the worms were established in the organically enriched sediment. Since UQ-10 is one of the co-enzymes used for aerobic respiration in the respiratory chain by the members of the class Alphaproteobacteria (Collins and Jones, 1981), it is very likely that the efficient decomposition of organic matter of the organically enriched sediment was not realized in the bioremediation experiments by the single effect of the feeding activity of Capitella, but was caused by the associated activities of Capitella with the microorganisms in the sediment (Chareonpanich et al., 1993; Tsutsumi et al., 2002; Kunihiro et al., 2008; Wada et al., 2008). Various biological activities of Capitella in the sediment, including burrowing into the sediment, spouting the subsurface sediment on the sediment surface, feeding the subsurface sediment and excreting fecal pellets on the sediment (Tsutsumi et al., 2005b), may act to a create more oxidized environment in the organically enriched sediment that is suitable for increase of aerobic bacteria $(\mathrm{Wu}$ et al., 2003; Wada et al., 2005).

This study aims at clarifying the interaction and association between Capitella sp. I and bacteria on the decomposition of organic matter in the organically enriched sediment. In the bioremediation experiments on the organically enriched sediment with mass-cultured colonies of Capitella, which were conducted in the fish farm in Amakusa, Japan, between June in 2004 and July in 2006, we collected the sediment from the sea floor just below the net pens of the fish farm monthly, monitored the changes of the microbial community to confirm the increase in the members of the class Alphaproteobacteria in the sediment with dense patches of Capitella colonies, using the quinone profiling method and the polymerase chain reaction (PCR)denaturing gradient gel electrophoresis (DGGE) technique, and tried to identify the Alphaproteobacterial species related with dense patches of Capitella colonies by PCR-DGGE of partial 16S rRNA genes. We discuss the ecological implications of the increase in the members of the class Alphaproteobacteria with the dense patches of Capitella colonies in the organically enriched sediment.

\section{Materials and methods}

\section{Study area}

Kusuura Bay is an enclosed bay $\left(11.4 \mathrm{~km}^{2}\right.$ area, $4 \times 3.5 \mathrm{~km}^{2}$ ), located between Amakusa Kamishima and Amakusa Shimoshima Islands in Kyushu, 
Western Japan $\left(130^{\circ} 13^{\prime} \mathrm{E}, 32^{\circ} 23^{\prime} \mathrm{N}\right)$. The water depth is approximately $16-20 \mathrm{~m}$ at the center of the bay. In 1973, fish farms were established in an area of approximately $400 \mathrm{~m}$ in length and $200 \mathrm{~m}$ in width in the eastern part of the bay. At the time of this study, 102 net pens $12 \mathrm{~m}$ square and $8 \mathrm{~m}$ deep were established as fish farms, with approximately 5-20 tons of red sea bream, Pagrus major, and yellowtail, Seriola quinqueradiata, being cultured in each of the pens.

We set two sampling stations, Stn $\mathrm{F}$ beside a fish-farm net pen, and Stn C approximately $400 \mathrm{~m}$ away from the fish farms. The mud content of the sediment at Stn F and Stn C was approximately $10 \%$ and $60 \%$, respectively. At Stn F, the total amount of reared fish in the net pens changed markedly from month to month (approximately 10-20 tons per net pen) because of their growth and shipping. The total amount of organic matter expended as food for the reared fish per month fluctuated between 0.28 and 2.48 ton-C per month from June 2004 to July 2006 (mean 0.93 ton-C per month), except February 2006 (0.01 ton-C per month). The feeding amount was adjusted to the physiological conditions of the reared fish. Masscultured colonies of Capitella sp. I were introduced on the organically enriched sediment just below the net pen $\left(12 \times 12 \mathrm{~m}^{2}\right)$ at Stn $\mathrm{F}$ on 5 November 2004 (approximately 9.27 million individuals) and 9 November 2005 (approximately 2.19 million individuals), respectively (Tsutsumi et al., 2005a; Kinoshita et al., 2008).

\section{Sampling of the sediment}

We conducted monthly sampling of sediments between June 2004 and July 2006. At Stn F, four sediment core samples were collected with acrylic hand core samplers ( $45 \mathrm{~mm}$ in diameter) by divers from each of five different points just below the four corners and the center of the net pen. One of these four core samples collected in each sampling point was used for determination of density and biomass of the Capitella population, and another was used for determination of sediment density, redox potential (ORP), TOC, quinone content and identification of bacteria with DGGE analysis. At Stn C, six sediment core samples were collected in the same manner as Stn F. Three of them were used for the determination of sediment density, ORP and quinone content and identification of bacteria. The remaining three samples were used for the determination of the density of sediment. We also collected a sediment core sample for the determination of TOC with a KK type core sampler $(40 \mathrm{~mm}$ in diameter), and three grab samples using an Eckman-Birge grab sampler $\left(20 \times 20 \mathrm{~cm}^{2}\right)$ from a boat. We subsampled 10 sediment samples from each with a core sampler $\left(5 \times 5 \times 5 \mathrm{~cm}^{3}\right)$ for the quantitative analysis of Capitella sp. I.
To identify the alphaproteobacterial species occurring around the body of Capitella, one sediment core sample was collected by divers at the center of the net pen at Stn F on 14 December 2006. We collected 10 individuals of live worms from the sediment core sample under a stereoscopic microscope, and kept them in a petri dish with sterilized artificial seawater for several hours. After we confirmed that the worms had excreted feces, we put them in a $1.5-\mathrm{ml}$ tube. The tube with the worms was stored in a freezer at $-20^{\circ} \mathrm{C}$ until used for DGGE analysis.

\section{Quantitative analysis of Capitella and} physico-chemical analysis of the sediment

For determination of the density and biomass of Capitella population, the sediment core samples were fixed, and stained in $10 \%$ formalin solution with a dye, Rose Bengal. The procedures of the treatment followed Kinoshita et al. (2008).

The sediment samples for determination of sediment density, ORP, TOC and quinone content, and DGGE of the sediment were sliced into two layers, the surface layer (up to a depth of $2 \mathrm{~cm}$ ) and the subsurface layer (from 2 to $4 \mathrm{~cm}$ in depth). For measurement of sediment density, the sliced sediment samples in each layer were dried at $110^{\circ} \mathrm{C}$ overnight. The sediment density was then calculated by dividing the dry weight by the volume $\left(33 \mathrm{~cm}^{3}\right)$. ORP of the sediment in each layer was determined with a platinum electrode (RM-20P, TOA DKK). TOC of sediment was determined following Kinoshita et al. (2008). We calculated the TOC content of the surface and subsurface layers of the sediment, and expressed as TOC $\mathrm{g} \mathrm{m}^{-2}$, using the sediment density data. At Stn F, ORP and TOC of the sediment were represented by the mean values of the sediment samples collected at five different sites just below the four corners and center of the net pen. At Stn C, they were represented by the mean values of three replicates of the sediment sample.

The remaining sediment samples after determination of ORP and TOC of the sediment were stored in a freezer at $-20^{\circ} \mathrm{C}$ until used for analysis of quinone content and DGGE. The surface sediment sample collected at Stn F on 8 March 2006 was used for isolating bacteria belonging to the Alphaproteobacteria.

\section{Analysis of quinone content of the sediment}

The microbial quinone content of the sediment was determined following the procedures adopted by Kunihiro et al. $(2005,2008)$. In this study, we refer to the quinones with the following abbreviations (ubiquinone: UQ- $n$, menaquinone: MK- $n$, plastoquinone: PQ- $n$, and phylloquinone (vitamin K1): VK1). The number $(n)$ indicates that of the isoprene unit in the side chain of the quinone. For example, UQ-10 represents a ubiquinone with 10 isoprenoid units. Partially hydrogenated MKs were expressed as 
Table 1 Major marine sediment bacteria and their dominant quinone species

\begin{tabular}{|c|c|c|}
\hline Bacterial division & Quinone species ${ }^{\mathrm{a}}$ & Marine sediment bacteria ${ }^{\mathrm{b}}$ \\
\hline Cyanobacteria & PQ, VK1 & \\
\hline Alphaproteobacteria & UQ-10 & $\begin{array}{l}\text { Azospirillum, Beijerinckia, Bradyrhizobium, Nitrobacter, Rhodomicrobium, } \\
\text { Rhodospirillum, Roseobacter, Sphingomonas }\end{array}$ \\
\hline Betaproteobacteria & UQ-8 & Nitrosomonas, Nitrospira \\
\hline Gammaproteobacteria & $\begin{array}{l}\text { UQ-8, UQ-9 } \\
\text { UQ-8 }\end{array}$ & $\begin{array}{l}\text { Beggiatoa, Chromatium, Ectothiorhodospira, Marinomonas, Proteus, } \\
\text { Pseudoalteromonas, Pseudomonas, Rhodocyclus, Shewanella, Vibrio, Xanthomonas }\end{array}$ \\
\hline Deltaproteobacteria & $\begin{array}{l}\text { MK-n }(n \leqslant 8) \\
\text { MK-6 } \\
\text { MK-7 } \\
\text { MK-8 }\end{array}$ & $\begin{array}{l}\text { Desulfomonas, Desulfovibrio } \\
\text { Desulfobacter, Desulfococcus, Desulfosarcina } \\
\text { Desulfuromonas, Mухососсиs }\end{array}$ \\
\hline Epsilonproteobacteria & $\begin{array}{l}\text { MK-6, MK-7 } \\
\text { MK-6 }\end{array}$ & Campylobacter \\
\hline Actinobacteria & $\begin{array}{l}\text { MK- } n(n \geqslant 9) \\
\text { MK-n(Hx) }\end{array}$ & Arthrobacter, Atopobium, Clavibacter, Corynebacterium, Microbacterium, Streptomyces \\
\hline $\begin{array}{l}\text { Bacteroidetes } \\
\quad \text { Flavobacteria } \\
\text { Sphingobacteria }\end{array}$ & $\begin{array}{l}\text { MK- } n(n \leqslant 8) \\
\text { MK-7 } \\
\text { MK-6 }\end{array}$ & $\begin{array}{l}\text { Flavobacterium } \\
\text { Cytophaga }\end{array}$ \\
\hline
\end{tabular}

Abbreviations: MK, menaquinone; PQ, plastoquinone; UQ, ubiquinone; VK1, vitamin K1.

aDominant quinone species that exist in the main species of the bacterial genus, from the WFCC-MIRCEN World Data Centre for Microorganisms (WDCM) database (1995).

${ }^{\mathrm{b}}$ The data were obtained from the references (Akagawa-Matsushita et al., 1992; James and Russell, 1996; Urakawa et al., 1999; Bissett et al., 2006).

MK- $n\left(H_{x}\right)$, where $x$ indicates the number of hydrogen atoms saturating the side chain. For example, MK-7 $\left(\mathrm{H}_{2}\right)$ represents an MK with seven isoprenoid units and one of the seven units is hydrogenated with two hydrogen atoms. In general, one species or genus of bacteria has only one dominant species of respiratory quinone, ubiquinone and MK (Hedrick and White, 1986; Hiraishi, 1999). Table 1 summarizes the correspondence between the phylogenetic assignment of bacteria and dominant quinone species.

UQ and MK are key components of the respiratory chain used for aerobic/nitrate and anaerobic/aerobic respirations, respectively (Collins and Jones, 1981; Hedrick and White, 1986; Hiraishi, 1999). The composition ratio of each group in the total quinone content may reflect the energy metabolic characteristics of the microbial community. Therefore, the analysis of UQ/MK ratio can be used to elucidate the respiratory status of the microbial community in the environment (Hedrick and White, 1986).

\section{DNA extraction and PCR amplification}

For DNA extraction from the sediment core samples and the sample of living worm bodies, we adopted a modified method based on Isoil kit (Nippon gene, Tokyo, Japan). A total of 0.5 g-wet sediment was put in a $1.5-\mathrm{ml}$ tube prior to the DNA extraction. Samples were centrifuged $(8000 \times g$ for $10 \mathrm{~min})$ three times with $1 \mathrm{ml}$ of PBS ( $8 \mathrm{~g}$ of $\mathrm{NaCl}, 0.2 \mathrm{~g}$ of $\mathrm{KCl}$, $2.88 \mathrm{~g}$ of $\mathrm{Na}_{2} \mathrm{HPO}_{4}$ and $0.48 \mathrm{~g}$ of $\left.\mathrm{KH}_{2} \mathrm{PO}_{4}, \mathrm{pH} 7.4\right)$, and pelletized by centrifugation ( $8000 \times g$ for $3 \mathrm{~min})$. Each pellet was re-suspended in $665 \mu \mathrm{l}$ of Lysis solution $\mathrm{HE}$ and $35 \mu \mathrm{l}$ of Lysis solution $20 \mathrm{~S}$ (supplied in the kit), and incubated at $65^{\circ} \mathrm{C}$ for $1 \mathrm{~h}$. The sample was frozen at $-80^{\circ} \mathrm{C}$ for $1 \mathrm{~h}$, and thawed at $65^{\circ} \mathrm{C}$ for $15 \mathrm{~min}$. The freeze-thaw cycle was repeated three times to increase DNA extraction efficiency. The following precipitation steps were performed according to the manufacturer's instruction (Nippon gene). Obtained DNA pellets were dried under vacuumed conditions, and re-dissolved in $100 \mu \mathrm{l}$ of TE buffer (10 mM Tris-HCl, $1 \mathrm{mM}$ EDTA-2Na, $\mathrm{pH}$ 8.0). Absorbency of the DNA solution was measured at $A_{260}$ with an ultraviolet-visible spectrophotometer (UV-2450(PC)S, Shimadzu, Kyoto, Japan) to determine the DNA concentration. Final extractions were stored at $-20{ }^{\circ} \mathrm{C}$ until used for PCR amplification.

Approximately $50 \mathrm{ng}$ of DNA extract was amplified by PCR with a Zymoreactor II AB1820 (ATTO, Tokyo, Japan). PCR amplification targeting bacterial $16 \mathrm{~S}$ rDNA was performed with the GC-341f (5' - CGC CCG CCG CGC CCC GCG CCC GTC CCG CCG CCC CCG CCC G-CC TAC GGG AGG CAG CAG-3') and 907r (5'-CCG TCA ATT CCT TT[A/G] AGT TT-3') (Muyzer et al., 1993). The PCR mixture contained $10 \mu \mathrm{l}$ of $10 \times$ PCR buffer, $200 \mu \mathrm{M}$ of each dNTP, $3.5 \mathrm{mM}$ of $\mathrm{MgCl}_{2}, \quad 100 \mu \mathrm{g} \mathrm{ml}^{-1}$ of bovine serum albumin (Roche Applied Science Biochemicals, Tokyo, Japan), $0.25 \mu \mathrm{M}$ of each primer, $2.5 \mathrm{U}$ AmpliTaq Gold (Applied Biosystems, Foster City, CA, USA) and sterile MilliQ water, for a final volume of $100 \mu \mathrm{l}$. The PCR amplification was performed for 35 cycles in a touchdown thermocycling program as follows: after initial denaturation for $9 \mathrm{~min}$ at $94{ }^{\circ} \mathrm{C}$, each cycle consisted of denaturation at $94^{\circ} \mathrm{C}$ for $1 \mathrm{~min}$, primer annealing at the annealing temperature $\left(T_{A}\right)$ for $1 \mathrm{~min}$ and primer extension at $72^{\circ} \mathrm{C}$ for $1 \mathrm{~min}$. In the first 15 cycles, $T_{\mathrm{A}}$ was decreased by $2{ }^{\circ} \mathrm{C}$ 
every 3 cycles, from $65{ }^{\circ} \mathrm{C}$ to $55^{\circ} \mathrm{C}$. In the last 20 cycles, $T_{\mathrm{A}}$ was $55^{\circ} \mathrm{C}$. Cycling was followed by a final primer extension at $72^{\circ} \mathrm{C}$ for $10 \mathrm{~min}$.

\section{DGGE analysis and sequencing analysis of DGGE bands}

The DGGE analysis was performed with a D-code universal mutation detection system (Bio-Rad Laboratories, Hercules, CA, USA). About $500 \mathrm{ng}$ of the amplified PCR product (approximately $25 \mu \mathrm{l}$ of the PCR product) was loaded onto an $8 \%(\mathrm{w} / \mathrm{v})$ acrylamide gel (acrylamide/bis solution, 37.5:1, Sigma-Aldrich Japan, Tokyo, Japan) containing a linear chemical gradient ranging from $20 \%$ to $70 \%$ denaturant $(100 \%$ denaturant consisted of $7 \mathrm{M}$ urea and $40 \%(\mathrm{v} / \mathrm{v})$ formamide). Electrophoresis was run at a constant voltage of $200 \mathrm{~V}$ for $6 \mathrm{~h}$ at $60^{\circ} \mathrm{C}$ in $0.5 \times$ TAE buffer ( $20 \mathrm{mM}$ Tris-HCl, $20 \mathrm{mM}$ sodium acetate, $0.5 \mathrm{mM}$ EDTA-2Na, pH 8.0). The gels were stained with SYBR Green I (Molecular Probes, Carlsbad, OR, USA) at $10000 \times$ dilution in MilliQ water for $30 \mathrm{~min}$, and then photographed on a UV transilluminator.

The gel photo was scanned, and the intensity of band peaks (not containing band background) was manually measured using WinROOF (MITANI Co., Fukui, Japan). The DGGE band profiles in each lane were constructed based on the intensities of the band peaks to the total intensity in the lane (Supplementary Table 1).

For the sequence analysis of the DGGE bands, the bands were excised from the gel, placed into sterile $0.5 \mathrm{ml}$ tubes and washed in order to exclude the urea using sterilized water. A small piece of the band served as a template for PCR amplification. The amplified products were subjected to a new DGGE step to confirm their electrophoretic mobility. The PCR products of the sequences obtained in this study were purified with an EXOSAP-IT kit (USB Corp., Santa Clara, OH, USA), sequenced using an ABI Prism BigDye Terminator cycle sequencing ready reaction kit (Applied Biosystems), and run on an ABI 3100 Genetic Analyzer (Applied Biosystems). The sequences obtained from the DGGE bands were compared with the Ribosomal Database Project data (release 10.23) with the Seqmatch version 3 to retrieve similar sequences and phylogenetically related species.

Cluster analysis based on the quinone profile or DGGE band profile

To evaluate the changes in the microbial community in the sediment, a dissimilarity index $(D)$ of microbial community was calculated using the following equation (Hiraishi et al., 1991).

$$
D(i, j)=\frac{1}{2} \sum_{k=1}^{n}\left|f_{k i}-f_{k j}\right|
$$

In quinone profiles, $f_{k i}$ and $f_{k j}$ are the mole fractions of the $k$ quinone component for the $i$ and $j$ samples, respectively. In the DGGE band profile, $f_{k i}$ and $f_{k j}$ are the fractions of the $k$ DGGE bands intensity for the $i$ and $j$ samples, respectively. Values $\leqslant 0.1$ of dissimilarity of quinones are not recognized as different quinone profiles $(97 \%$ statistical reliability; Hu et al., 2001). Cluster analysis was performed with the StatPartner program (O-Ha Inc., Tokyo, Japan) based on the distance matrix, and a dendrogram was constructed using the between-groups linkage method.

\section{Isolation of bacteria from the fish-farm sediment}

We attempted to isolate alphaproteobacterial species from the surface sediment that was collected at Stn F in 8 March 2006. The samples diluted in a 10-fold series with filtrated natural seawater. A total of $0.1 \mathrm{ml}$ of each dilution were spread on Shioi medium plates (Shioi, 1986), and were subsequently incubated at $20^{\circ} \mathrm{C}$ under light conditions for 2 weeks. Pinkcolored colonies were picked up from one of these plates, and again grown on Shioi's medium. This purification procedure was repeated several times until we obtained a single strain. The DNA extraction and sequencing of the $16 \mathrm{~S}$ rDNA of the isolated bacteria were performed as described above.

Phylogenetic analysis and sequence accession numbers The sequences obtained from the DGGE bands of the alphaproteobacterial species, the isolated bacteria and their similar sequences cited from the Ribosomal Database Project data (release 10.23) were aligned. Phylogenetic trees were constructed by the neighbor-joining method using the ClustalX version 2.1 (Thompson et al., 1997) and visualized using NJplot (Perrière and Gouy, 1996).

The 16S rDNA sequences of the DGGE bands (bands 6, 7, 8, CB) and the isolated bacteria (KMUT1, 3-7) have been deposited under DDBJ accession numbers from AB583757 to AB583767 and from AB583769 to AB583773.

\section{Statistical analysis}

Analysis with Pearson's correlation coefficient was performed using the statistical program PASW Statistics for Windows version 18J (IBM Japan, Tokyo, Japan).

\section{Results}

Fluctuations of Capitella population, ORP, TOC and quinone content of the sediment

Figure 1 shows fluctuations of the densities of Capitella sp. I and three parameters of the environmental conditions of the sediment including ORP, TOC and quinone content at Stn F (inside the fish farm) and Stn C (approximately $400 \mathrm{~m}$ apart from the fish farm). At Stn F, the density of Capitella sp. I decreased to extremely low levels of $<1500$ individuals 


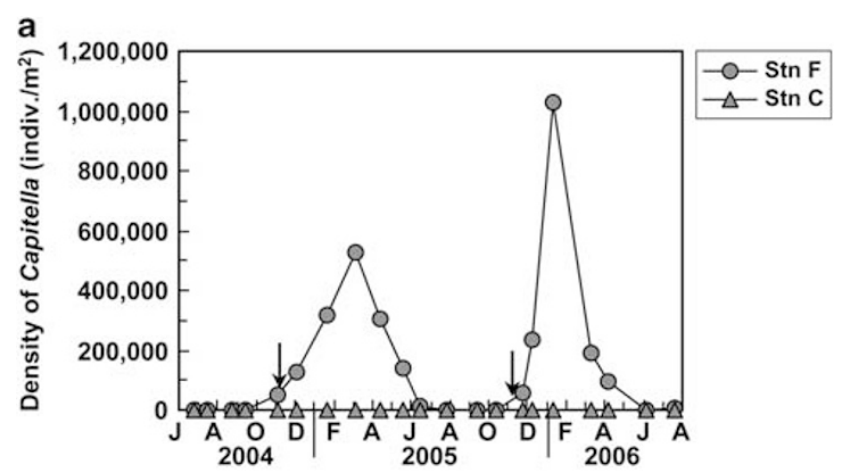

b

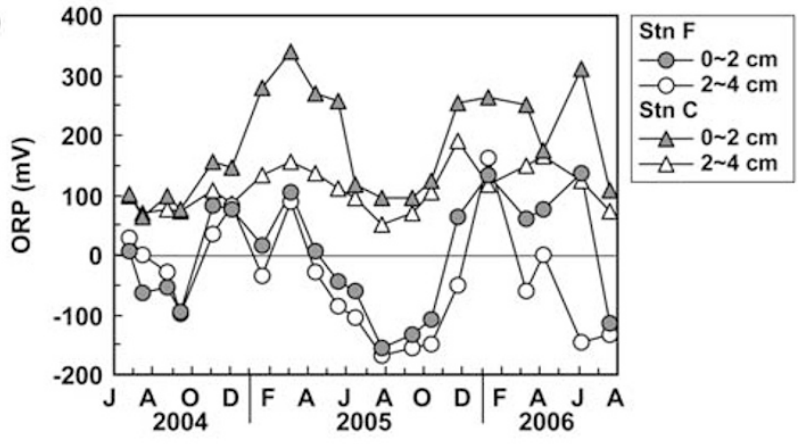

C
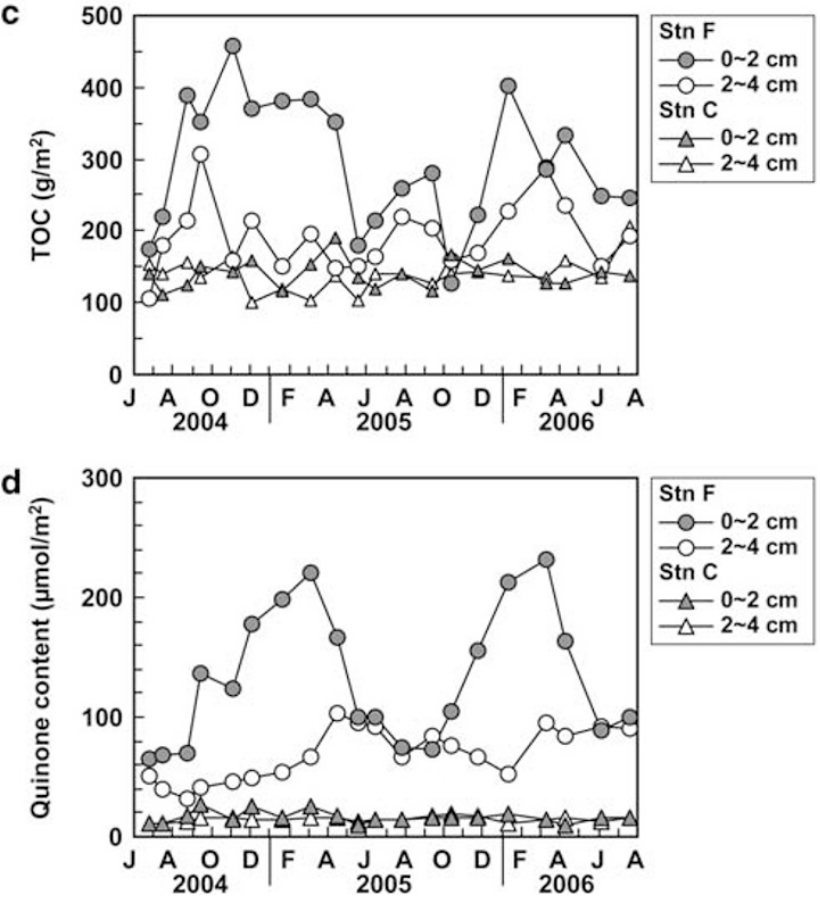

Figure 1 Fluctuations in (a) density of Capitella, (b) ORP, (c) TOC and (d) quinone content of the surface layer (up to a depth of $2 \mathrm{~cm}$ ) and the subsurface layer (from $2 \mathrm{~cm}$ to $4 \mathrm{~cm}$ in depth) of the sediment at Stn F and Stn C. Arrows indicate the release of mass-cultured colonies of Capitella sp. I at Stn F. Plots of Capitella density and TOC content of the sediment are modified from Kinoshita et al. (2008). Plots of ORP and quinone content of the sediment between May 2004 and September 2005 are modified from Kunihiro et al. (2008).

per $\mathrm{m}^{2}$ in the summer, when reduced conditions developed in the organically enriched sediment $(-1$ to $-99 \mathrm{mV}$ between July and September 2004,
-44 to $-170 \mathrm{mV}$ between May and October 2005 and -115 to $-135 \mathrm{mV}$ in July 2006 in the sediment depth of $4 \mathrm{~cm}$; Figure 1b), following the occurrence of hypoxic water in the bottom water (Srithongouthai et al., 2006). The density of Capitella sp. I tends to recover naturally during the autumn to winter, when oxygen-rich water is supplied to the bottom layers by the vertical mixing of the water, and consequently oxidized conditions are formed in the surface layer of the sediment (Tsutsumi and Kikuchi, 1983; Tsutsumi, 1987, 1995; Tsutsumi, 1990; Srithongouthai et al., 2006). In this study, ORP of the surface layer of the sediment (up to a depth of $2 \mathrm{~cm}$ ) at $\mathrm{Stn} \mathrm{F}$ recovered to +82 to $+5 \mathrm{mV}$ between November 2004 and April 2005, and +65 to + $135 \mathrm{mV}$ between November 2005 and June 2006 . We had attempted to accelerate the recovery of the Capitella population by the introduction of masscultured colonies and to promote bioremediation of the organically enriched sediment at Stn F since 2003 (Kinoshita et al., 2008; Tsutsumi et al., 2005a), and succeeded to realize an explosive population increase in the autumn to winter of 2004 and 2005. The density of Capitella population reached 528000 individuals per $\mathrm{m}^{2}$ in March 2005 and 1028000 individuals per $\mathrm{m}^{2}$ in January 2006.

The organic matter content of the sediment is expressed in terms of TOC content of the sediment per square meter, since the water content of the sediment changed markedly in the process of this study. At Stn F, TOC content of the sediment in June was $213 \pm 36 \mathrm{~g}^{-\mathrm{C} \mathrm{m}^{-2}}$ (mean \pm s.d.) in the surface layer (up to a depth of $2 \mathrm{~cm}$ ) and $140 \pm 31 \mathrm{~g}-\mathrm{Cm}^{-2}$ in the subsurface layer $(2-4 \mathrm{~cm}$ in depth) during the 3 years between 2004 and 2006. It was only slightly higher than that in the surface layer $\left(133 \mathrm{~g}-\mathrm{Cm}^{-2}\right)$, and almost equivalent to that in the subsurface layer $\left(143 \mathrm{~g}^{-} \mathrm{C} \mathrm{m}^{-2}\right)$ at Stn C outside the fish farm, since the sediment at Stn F had been treated with Capitella colonies since the cold seasons between the winter in 2003 and early spring in 2004 (Tsutsumi et al., 2005a; Kinoshita et al., 2008). However, TOC content of the surface layer of the sediment increased markedly in the autumn to early winter, and reached $459 \mathrm{~g}-\mathrm{Cm}^{-2}$ by November 2004 and $403{\mathrm{~g}-\mathrm{C} \mathrm{m}^{-2}}$ by January 2006, since the organic matter discharged from the net pens, such as feces of reared fish and food residues deposited on the sea floor intensively just below the net pens due to vertical mixing of the water (Tsutsumi et al., 2006). The increase in TOC content of the sediment in the subsurface layer of the sediment was much less distinct than that in the surface layer. We noted a peak $306 \mathrm{~g}-\mathrm{C} \mathrm{m}^{-2}$ in September 2004 and $286 \mathrm{~g}-\mathrm{Cm}^{-2}$ in March 2006. When the sediment was kept relatively oxidic, and dense patches of Capitella sp. I of $>100000$ individuals per $\mathrm{m}^{2}$ were formed between the winter and the spring, TOC of the surface layer of the sediment decreased, and returned to the level that was almost equivalent to that in June of the previous year $\left(179 \mathrm{~g}-\mathrm{Cm}^{-2}\right.$ in May 
2005 and $248 \mathrm{~g}-\mathrm{Cm}^{-2}$ in June 2006). At Stn C, both layers of the sediment were kept oxidic $(+52$ to $+340 \mathrm{mV}$ ), and the TOC contents of the sediment fluctuated in a low range between 101 and $205 \mathrm{~g}$ $\mathrm{Cm}^{-2}$ throughout the period of this study. Such oxidic conditions of the sediment did not seem to restrict the occurrence of the macro-benthic animals, but Capitella sp. I remained at extremely low densities of $<320$ individuals per $\mathrm{m}^{2}$ in all seasons. It seems that Capitella sp. I does not favor the less organically enriched sediment as a habitat.

Quinone content of the sediment, which indicates the abundance of microorganisms in the sediment, increased markedly in the surface layer at Stn F between the autumn and the spring of the next year, and reached a peak in March $\left(220 \mu \mathrm{mol} \mathrm{m}^{-2}\right.$ in 2005 and $232 \mu \mathrm{mol} \mathrm{m}^{-2}$ in 2006). These two peaks of quinone content in the surface layer of the sediment were delayed from those of TOC content of the sediment approximately for 4 and 2 months, respectively. Figure 2 compares the relationships (a) between TOC and quinone content in the surface
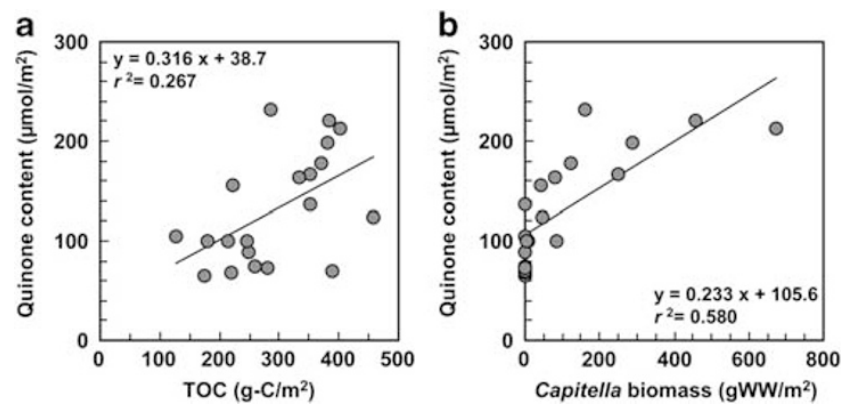

Figure 2 Comparisons (a) between TOC and quinone content and (b) between Capitella biomass and quinone content in the surface layer (from the surface to $2 \mathrm{~cm}$ in depth) of the sediment at Stn F. layer of the sediment and (b) between biomass of Capitella sp. I in the sediment up to a depth of $5 \mathrm{~cm}$ and quinone content in the surface layer of the sediment at Stn F. The relationship between TOC and quinone content of the sediment was not clear $\left(r^{2}=0.267\right)$, while a significant positive correlation was found between biomass of Capitella sp. I and quinone content of the sediment (Pearson's correlation coefficient, $\left.r^{2}=0.580, P<0.05\right)$. These results indicate that the abundance of bacteria in the surface layer of the sediment did not change simply depending on the organic matter content of the sediment, but increased in association with Capitella colonies in the organically enriched sediment.

Changes in the quinone profile of the surface sediment Figure 3 shows changes in the quinone profiles of the surface layer of the sediment at Stn F and Stn C. At Stn F, UQ-10 predominated in the mole fraction of quinone in the sediment. It occupied 30.5-47.4\% in the quinone composition of the sediment throughout the period of this study, and tended to increase from the autumn to winter $(47.4 \%$ in December 2004 and $42.7 \%$ in January 2006), when dense patches of Capitella sp. I were established. UQ-8, which is present in the members of the class Gammaproteobacteria, fluctuated in the second largest ratio (10.4-17.4\%) in the quinone composition of the sediment. MK-7, which is present in the members of the class Deltaproteobacteria and class Flavobacteria, occupied $5.0-8.7 \%$ of the quinone composition of the sediment. The partially hydrogenated MKs, which is present in the members of the phylum Actinobacteria, accounted for 2.6-12.3\% of the quinone composition of the sediment throughout the period of this study. The photosynthetic quinones (PQ and vitamin K1), which are present in photosynthetic microorganisms, such as

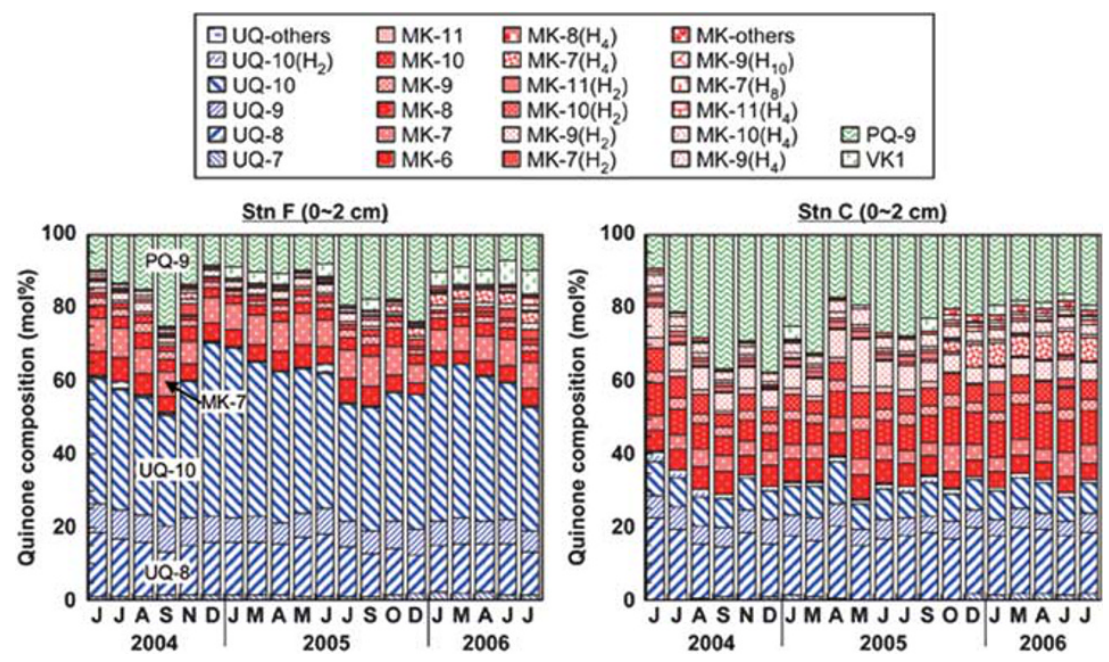

Figure 3 Changes in the mole fractions of quinone of the surface layer (up to a depth of $2 \mathrm{~cm}$ ) and the subsurface layer (from $2 \mathrm{~cm}$ to $4 \mathrm{~cm}$ in depth) of the sediment. Plots between May 2004 and September 2005 are modified from Kunihiro et al. (2008). 
micro-algae and cyanobacteria, fluctuated from $8.3 \%$ to $25.3 \%$ of the total quinone content of the sediment throughout the period of this study, and tended to increase in the warm seasons. We inferred that the photosynthetic quinones were derived from benthic algae or phytoplankton deposited on the sediment. At Stn C, the photosynthetic quinones predominated in the quinone composition in the surface layer of the sediment throughout the period of this study (9.4-37.3\%). The composition of UQ-8 of the sediment fluctuated in a similar range, 13.6$22.4 \%$, with that at Stn F, while the composition of UQ-10 of the sediment did not increase in the cold seasons $(6.9-11.5 \%)$.

Figure 4 compares the content of each quinone species in the surface layer of the sediment at Stn F between the high-density period (480001028000 individuals per $\mathrm{m}^{2}$, November 2004 to May 2005 and November 2005 to April 2006) and the low-density period (0-13000 individuals per $\mathrm{m}^{2}$, June to September in 2004, June to October in 2005

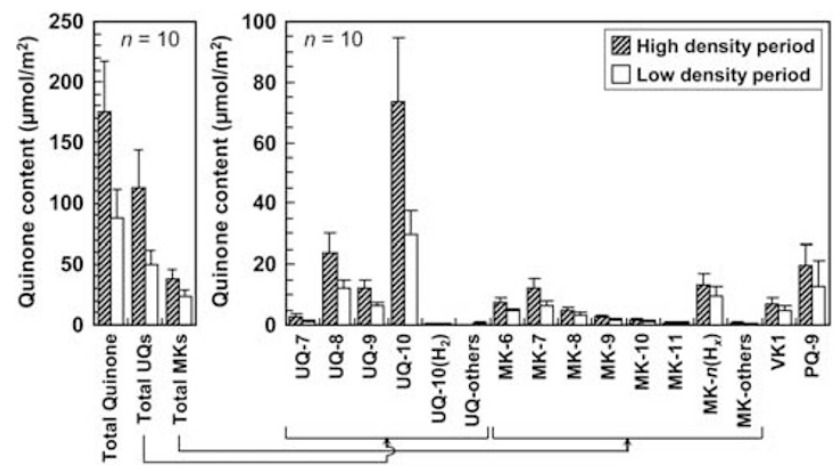

Figure 4 Comparison of the content of each quinone species in the surface layer of the sediment (up to a depth of $2 \mathrm{~cm}$ ) at Stn F between the high- and low-density periods of Capitella population. and June to July in 2006) of Capitella sp. I. The total quinone content of the sediment in the highdensity period of the worm, $175 \pm 42.2 \mu \mathrm{mol} \mathrm{m}{ }^{-2}$ (mean \pm s.d., $n=10$ ), was approximately 2.0 times higher than that in the low-density period $\left(88.0 \pm 22.6 \mu \mathrm{mol} \mathrm{m}^{-2}, n=10\right)$. In particular, the total UQs content of the sediment increased in the highdensity period $\left(113 \pm 30.6 \mu \mathrm{mol} \mathrm{m}^{-2}\right)$ to a level approximately 2.3 times higher than that in the low-density period $\left(50.1 \pm 11.9 \mu \mathrm{mol} \mathrm{m}^{-2}\right)$, while the mean total MKs content increased 1.7 times in the high-density period $\left(38.6 \pm 7.5 \mu \mathrm{mol} \mathrm{m}^{-2}\right)$ to that in the low-density period $\left(23.2 \pm 5.0 \mu \mathrm{mol} \mathrm{m}^{-2}\right)$. Among the UQs, the increase of the content of UQ-10 of the sediment was most distinct between the lowand high-density periods of Capitella sp. I (29.9 \pm $7.5 \mu \mathrm{mol} \mathrm{m}^{-2}$ and $73.5 \pm 21.0 \mu \mathrm{mol} \mathrm{m}^{-2}$, respectively). Therefore, these results on the increase of UQs content in the surface layer of the sediment with dense patches of Capitella sp. I reveal the association of bacteria, in particular, the members of the class Alphaproteobacteria containing UQ-10 with Capitella colonies in their increases in the organically enriched sediment in the cold seasons.

Cluster analysis based on the DGGE band pattern and the quinone profile

The composition of major species of the bacterial community was visualized in the surface layer of the sediment at Stn F and Stn C by PCR-DGGE, using the sediment samples collected in July and September in 2004; January, March, June and September in 2005 and January and March in 2006. In all, 18 DGGE bands (band 1-18) were detected on the gel for DGGE analysis in total at both stations (see Supplementary Table 1). Figure 5a shows the results of cluster analysis with the dissimilarity value
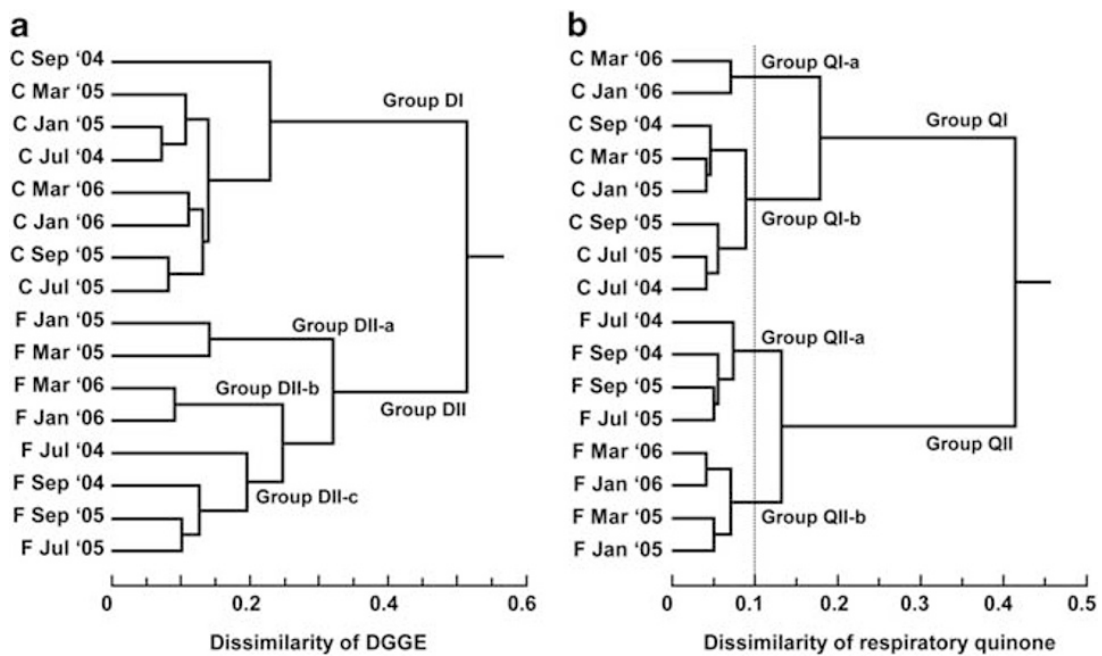

Figure 5 The results of the cluster analysis with the dissimilarity value matrix data calculated from (a) the DGGE band profiles of the sediment samples and (b) the mole fractions of respiratory quinones of the same sediment samples for DGGE analysis. Abbreviation of each sample indicates the sampling site and period. For example, C Mar '06 represents sampling at Stn C in March 2006. 
matrix data calculated from the DGGE band profiles of the sediment samples. The DGGE band profiles were divided clearly into two different major groups, group DI (Stn C) and group DII (Stn F) in the dendrogram with dissimilarity of DGGE. It indicates that the bacteria community composition of the sediment was markedly different between the outside and inside of the fish farm. Group DII was divided further into three groups, group DII-a (January and March in 2005), group DII-b (January and March in 2006) and group DII-c (July 2004 and September in 2004 and July and September in 2005). Group DII-a and group DII-b were characterized by the presence of distinct bands 7 and 8 in the DGGE band profiles, although the bands in group DII-b were relatively thin, and coincided with the periods that dense patches of Capitella sp. I were established (192 000-1028000 individuals per $\mathrm{m}^{2}$ ). In the case of group DII-c, band 7 was formed thinly and band 8 was absent.

Figure $5 \mathrm{~b}$ shows the results of the cluster analysis with the dissimilarity value matrix data calculated from the mole fractions of respiratory quinones of the same sediment samples for DGGE analysis. The dendrogram on the respiratory quinone profiles was also divided clearly into two different major groups, group QI (Stn C) and group QII (Stn F), and each of them was divided further into two minor groups (group QI-a and QI-b, group QII-a and QII-b). The sediment samples of group QI-a (Stn C in January and March in 2006) were characterized by relatively high mole fractions of the partially saturated MKs in the quinone composition of the sediment in comparison with those of group QI-b (see July and September in 2004, and January, March, July and September in 2005 in Figure 3). The sediment samples of group QII-a were collected at Stn F in the warm seasons (July and September in both of 2004 and 2005), while those of group QII-b were collected at the same station in the cold seasons (January and March in both of 2005 and 2006), when dense patches of Capitella sp. I (1920001028000 individuals per $\mathrm{m}^{2}$ ) were established (see
Figure 1a). Group QII-b was characterized by the highest levels of UQ-10 mole fraction in the quinone composition of the sediment $(42.2-47.4 \%$, see Figure 3), and corresponds to group DII-a and DII-b with distinct bands 7 and 8 in the DGGE band profiles in Figure 5a. Since UQ-10 is one of the co-enzymes used for aerobic respiration in the respiratory chain by the members of the class Alphaproteobacteria (Table 1), it is very likely that the bacteria with bands 7 and 8 , which increased in the sediment with dense patches of Capitella sp. I, are the members of the class Alphaproteobacteria.

\section{Phylogenetic affiliation of the DGGE bands and the} isolated bacteria from the sediment below the fish farm Nine distinct bands in the 15 bands observed on the lane in the DGGE gel at Stn F were excised and sequenced, and their phylogenetic affiliations were determined using 16S rRNA gene sequences (Table 2). Three of them, the bacteria with bands 6-8, were identified commonly as the members of the family Rhodobacteraceae in the class of Alphaproteobacteria on which we are focusing in this study (Figure 6).

To confirm the increase of the bacteria belonging to the family Rhodobacteraceae in the organically enriched sediment with dense patches of Capitella sp. I at Stn F in the cold seasons, we collected the worms at Stn F on 14 December 2006, and identified the dominant bacteria attached on the body of the worms with 16S rRNA gene sequences. We found one distinct band (band CB) on the DGGE lane with the extract from the body tissues of the worms (Table 2), which was very close genetically to the bacteria in the family Rhodobacteraceae with band 7 (the similarity in phylogenetic affiliation between them was $98.6 \%(556 / 564))$. The bacteria with band CB was notably predominant in the bacterial community around the body of Capitella sp. I, because the DGGE profile tends to detect only abundant species, not all species in the complex bacterial community.

Table 2 Sequence analysis of bands excised from DGGE gels with bacterial 16S rDNA

\begin{tabular}{|c|c|c|c|c|}
\hline Band & Highest similarity & Homology & Phylum/class & Dominant quinone ${ }^{a}$ \\
\hline 1 & Uncultured bacterium Hg92C2 (EU236396) & $567 / 586(96.7)$ & Flavobacteria & MK-6, 7 \\
\hline 3 & Uncultured bacterium 76IIIOMF3 (GU197418) & $566 / 582(97.2)$ & Flavobacteria & MK-6, 7 \\
\hline 5 & Uncultured bacterium VHS-B3-86 (DQ394967) & $532 / 547(97.2)$ & Gammaproteobacteria & UQ-8 \\
\hline 6 & Alphaproteobacterium MGP-80 (AF530151) & 487/501 (97.2) & Alphaproteobacteria & UQ-10 \\
\hline 7 & Rhodobacteraceae bacterium SH4-1 (FJ882053) & $565 / 586(96.4)$ & Alphaproteobacteria & UQ-10 \\
\hline 8 & Uncultured bacterium D7_10.4_1 (FJ716886) & $558 / 582(95.9)$ & Alphaproteobacteria & UQ-10 \\
\hline 13 & Uncultured actinobacterium 3G-1820-55 (DQ431888) & $425 / 434(97.9)$ & Actinobacteria & MK- $n(n \geqslant 9)$, MK- $n(\mathrm{Hx})$ \\
\hline 14 & Uncultured bacterium 096B62 (EU735002) & $565 / 568(99.5)$ & Actinobacteria & MK-n $(n \geqslant 9)$, MK-n(Hx) \\
\hline 16 & Uncultured bacterium Amsterdam-1B-57 (AY592358) & 497/524 (94.8) & Actinobacteria & MK- $n(n \geqslant 9)$, MK-n(Hx) \\
\hline $\mathrm{CB}$ & Rhodobacteraceae bacterium SH4-1 (FJ882053) & $561 / 563(99.6)$ & Alphaproteobacteria & UQ-10 \\
\hline
\end{tabular}

Abbreviations: DGGE, denaturing gradient gel electrophoresis; MK, menaquinone; PQ, plastoquinone; UQ, ubiquinone.

Band CB on the DGGE lane was derived from the extract of the body tissues of Capitella sp. I.

a Dominant quinone species that exist in the main species of the bacterial genus, from the WFCC-MIRCEN World Data Centre for Microorganisms (WDCM) database and references (Collins and Jones, 1981; Yokota et al., 1992). 


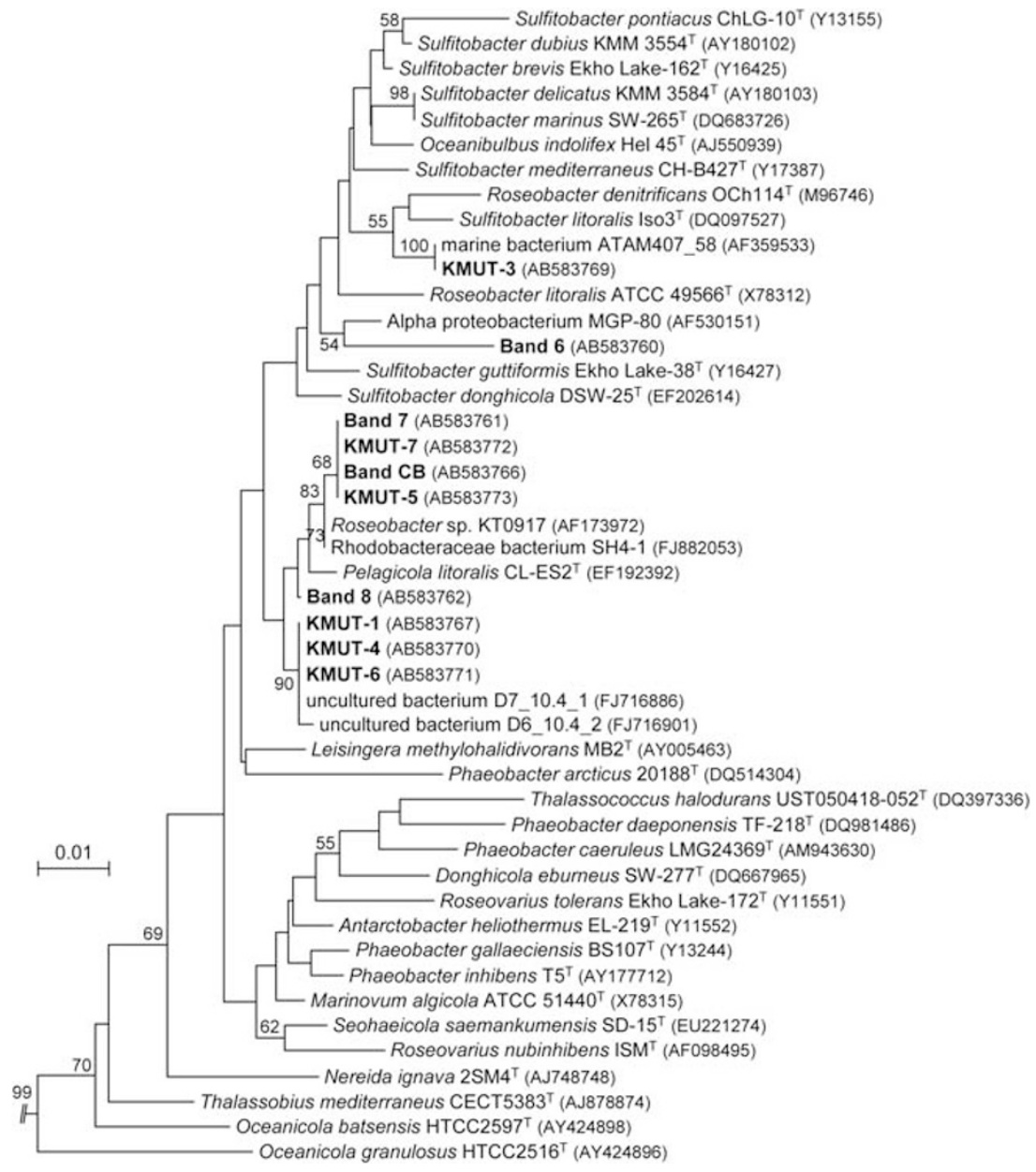

Figure 6 Phylogenetic affiliation of Roseobacter clade members described by comparative analysis of $16 \mathrm{~S}$ rDNA sequences (approximately $500 \mathrm{bp}$ ) from the DGGE fragments (band numbers: 6, 7, 8, CB), the isolated bacteria (KMUT-1, 3, 4, 5, 6, 7) and those stored in the public nucleotide database. 'Band' and 'KMUT' indicate sequences of DGGE bands and isolated bacteria, respectively. Ensifer meliloti IAM12611 ${ }^{\mathrm{T}}$ and Rickettsia prowazekii ${ }^{\mathrm{T}}$ were used as outgroup (not shown) to define the root of the tree. The scale bar represents $1 \%$ estimated difference divergence. The bootstrap values (\%) indicate the value of 1000 replicate trees supporting the branching order. Numbers at the nodes represent bootstrap values (only $>50 \%$ are shown) from 1000 replicates. Accession numbers are given in parentheses.

We attempted to isolate the alphaproteobacterial species from the surface layer of the sediment collected at Stn F on 8 March 2006. We obtained 73 colonies on a Shioi medium plate, chose seven colonies randomly from them, and sequenced their 16S rRNA genes. Six of the chosen seven colonies were identified as the members of the family Rhodobacteraceae, which were referred to the strain KMUT-1, 3, 4, 5, 6 and 7 in the phylogenetic tree of the partial Roseobacter clade (Figure 6; Supplementary Figure 1; Supplementary Table 2). Although the phylogenetic affiliations of these isolated bacteria were not determined because of the complexity of the community structure in the Roseobacter clade, three bacteria named as KMUT-1, 4 and 6 were located close to the Phaeobacter group, and the remaining three bacteria (KMUT-3, 5 and 7) were located close to the Sulfitobacter group (Supplementary Figure 1). The sequence similarities between band CB and KMUT5 and between band CB and KMUT7 were 99.8\% (562/563), and indicated that these bacteria belonged to the same bacterial genus. These results indicated that the bacteria associated with Capitella colonies were located at the narrow part of the partial Roseobacter clade.

\section{Discussion}

In this study, we conducted bioremediation experiments on the organically enriched sediment deposited just below a fish farm (Stn F), introducing artificially mass-cultured colonies of Capitella sp. I on the sea floor in early November in 2004 and 2005 (Tsutsumi et al., 2005a; Kinoshita et al., 2008). The Capitella colonies increased rapidly in the cold seasons, and reached a peak density in March 2005 (528000 individuals per $\mathrm{m}^{2}$ ) and January 2006 (1028000 individuals per $\mathrm{m}^{2}$ ) (Figure 1a). The quinone content of the surface sediment (up to a 
depth of $2 \mathrm{~cm}$ ), which indicates the abundance of microorganisms, also increased rapidly in the organically enriched sediment in the cold seasons in 2004 and 2005 (Figure 1d), although the activities of microorganisms vary depending on the water temperature in general (Ratkowsky et al., 1982; Pomeroy and Wiebe, 2001). Furthermore, the increase in the quinone content of the sediment did not depend on the organic matter content of the sediment, but depended rather on the biomass of Capitella population in the sediment (Figure 2). As the biomass of Capitella population increases in the sediment, the biological activities of the worms, such as feeding and reworking the sediment, exert a larger impact on the exchange of water at the interface of the sediment and the overlying water, and can contribute to the creation of a more oxidized environment suitable for increase of aerobic bacteria in the sediment (Wu et al., 2003; Wada et al., 2005).

Capitellid polychaetes including Capitella sp. I in this study are deposit feeders occurring in the sediment. They secrete a protein-rich mucopolysaccharide to agglutinate sediment grains and create tubes and burrows (Zola, 1967; Fauchald and Jumars, 1979), which is a labile organic matter and exploitable easily as one of the resources for increase of the microorganisms (Aller and Aller, 1986; Arnosti et al., 1994). The organic matter that is fed, digested and assimilated by the worms is used not only for growth and reproduction of the worms, but also is excreted partly as a mucopolysaccharide around the worms, and utilized by the microorganisms; in other words, it is used to stimulate further increase in the microorganisms. Actually, Alongi (1985) and $\mathrm{Wu}$ et al. (2003) reported that the microorganisms increased and worked actively around the inner walls of the burrows of Capitella in the sediment.

It is interesting to note that the Alphaproteobacteria consistently dominated in the microbial community in the fish-farm sediment throughout the study period (Figure 3). Previous studies reported that increases in Alphaproteobacteria were triggered by an addition of organic matter in seawater (Pinhassi et al., 1999; Cottrell and Kirchman, 2000b; Elifantz et al., 2005, 2007; Malmstrom et al., 2005; Nogales et al., 2007; Yokokawa and Nagata, 2010). The Alphaproteobacteria relative to other phylogenetic groups contributes to uptake of lowmolecular weight DOM, such as amino acids, protein, glucose and $N$-acetyl-glucosamine in various marine environments (Cottrell and Kirchman, 2000a; Malmstrom et al., 2005; Alonso and Pernthaler, 2006; Elifantz et al., 2007; Yokokawa and Nagata, 2010). The Alphaproteobacteria, therefore, has significant roles in decomposing and assimilating of the organic matter in the organically enriched sediment. The increase in the Alphaproteobacteria was positively correlated with the dense patches of the Capitella under oxidized conditions of the organically enriched sediment
(Figures 1b, 2b and 4). This suggests that the Capitella activities promote the increase in the Alphaproteobacteria by providing an oxygen-rich environment, which is suitable for them in the organically enriched sediment.

In this study, we succeeded in identifying the bacteria that increased around Capitella sp. I in the organically enriched sediment as the members of the Roseobacter clade in the class of Alphaproteobacteria (the majority of them belong to the family Rhodobacteraceae) (Figure 6). Band 8 was observed only in the sediment samples during the highdensity period of Capitella sp. I (192 000-1 028000 individuals per $\mathrm{m}^{2}$ ) (Supplementary Table 1). The increase in the Rhodobacteraceae species with band 8 is strongly associated with the establishment of dense patches of Capitella sp. I that contributed to decomposition of the organic matter in the sediment. The marine Roseobacter clade members are primary colonizers of surfaces in marine environments (Dang and Lovell, 2000; Dang et al., 2008), and relate to degradation of a multitude of organic compounds, sulfur metabolism, production of antibacterial compounds and symbiotic relationships with diverse marine eukaryotes (Moran et al., 2003, 2007; Brinkhoff et al., 2008). The growth of the partial Roseobacter clade members might be promoted further by the gradient in the physicochemical properties of the burrow environment (Marinelli et al., 2002) and stimulatory effects of grazing by Capitella species and protozoa (Alongi, 1985; Plante and Shriver, 1998).

For a future study on the association of the Roseobacter clade members with Capitella sp. I, we are trying to make clear the question why Capitella stimulates the increase of bacteria around the burrows. Hylleberg (1975) proposed a concept 'bacterial gardening' by which infaunal macrobenthic animals promote the increase of bacteria in the sediment through the arrangement of oxygenrich environment by their biological activities. The increase of bacteria around the inner walls of the burrows of Capitella is one of the typical cases of this gardening. Although the concept of bacterial gardening does not refer to the benefits of the benthic animals, the behaviors of the worms that stimulate the bacterial growth in the sediment will become meaningful for abundance, if they can get some benefits through the increase of bacteria, such as increase of available food resource. Several previous studies have suggested a potential role of the bacteria occurring in the sediment as one of the important food resources for deposit-feeding polychaetes (Haines and Montague, 1979; Findlay and Tenore, 1982; Tsutsumi et al., 2001), and confirmed that $>50 \%$ of bacteria are digested and eliminated in their guts in various polychaetes (Cammen, 1980; Grossmann and Reichardt, 1991; Lucas and Bertru, 1997).

From the standpoint of bioremediation of the organically enriched sediment with Capitella 
colonies, the phenomenon in which the organically enriched sediment is treated very efficiently following the increase of Capitella colonies very efficiently (Tsutsumi et al., 2005a; Kinoshita et al., 2008; this study) would become explicable not only empirically but also theoretically, if we assumed mutual interaction between the Capitella colonies and the bacteria around the worms in the sediment. If the Capitella could exploit the bacteria as a food resource, the stimulation of increase of the aerobic bacteria by arrangement of oxidized environment in the sediment and excretion of labile organic matter would contribute to an increase in the food resource for Capitella, since the digestible organic matter for Capitella is limited even in the organically enriched sediment. In the associated system with Capitella and the bacteria in the organically enriched sediment, the decomposition of the organic matter will proceed very rapidly, as we observed in actual bioremediation experiments (Tsutsumi et al., 2005a; Kinoshita et al., 2008; this study). It is very likely that Capitella sp. I works as a promoter of bacteria in the organically enriched sediment, and feeds the increased bacteria as one of the main foods, while the bacteria decompose the organic matter in the sediment with the assistance of Capitella for arrangement of the suitable environment. In a future study, we will attempt to clarify the question whether Capitella sp. I can utilize the members of the Roseobacter clade of the microorganisms as a food resource.

\section{Acknowledgements}

We express our thanks to Mr Richard Lavin and Dr Todd $\mathrm{W}$ Miller for their critical reading of the manuscript. $\mathrm{Mr}$ Takayoshi Hisada (Technical Department NCIMB group, Techno Suruga Laboratory Co., Ltd) helped with the phylogenetic analysis of this study. This research was supported by the Research and Development Program for New Bio-industry Initiatives of the Bio-oriented Technology Research Advancement Institution (BRAIN) of Japan. This work partly was supported by Grant-in-Aid for Young Scientists (B, 21710081) and by Sasakawa Scientific Research Grant from The Japan Science Society.

\section{References}

Akagawa-Matsushita M, Itoh T, Katayama Y, Kuraishi H, Yamasato K. (1992). Isoprenoid quinone composition of some marine Alteromonas, Marinomonas, Deleya, Pseudomonas and Shewanella species. J Gen Microbiol 138: 2275-2281.

Aller JY, Aller RC. (1986). Evidence for localized enhancement of biological activity associated with tube and burrow structures in deep-sea sediments at the HEBBLE site, western North Atlantic. Deep-Sea Res 33: 755-790.

Aller RC, Yingst JY, Ullman WJ. (1983). Comparative biogeochemistry of water in intertidal Onuphis (Polychaeta) and Upogebia (Crustacea) burrows: temporal patterns and causes. J Mar Res 41: 571-604.
Alongi DM. (1985). Microbes, meiofauna, and bacterial productivity on tubes constructed by the polychaete Capitella capitata. Mar Ecol Prog Ser 23: 207-208.

Alonso C, Pernthaler J. (2006). Roseobacter and SAR11 dominate microbial glucose uptake in coastal North Sea waters. Environ Microbiol 8: 2022-2030.

Arnosti C, Repeta DJ, Blough NV. (1994). Rapid bacterial degradation of polysaccharides in anoxic marine systems. Geochim Cosmochim Ac 58: 2639-2652.

Bissett A, Bowman J, Burke C. (2006). Bacterial diversity in organically-enriched fish farm sediments. FEMS Micorbial Ecol 55: 48-56.

Brinkhoff T, Giebel H-A, Simon M. (2008). Diversity, ecology, and genomics of the Roseobacter clade: a short overview. Arch Microbiol 189: 531-539.

Buschmann AH, Riquelme VA, Hernández-González MC, Varela D, Jiménez JE, Henríquez LA et al. (2006). A review of the impacts of salmonid farming on marine coastal ecosystems in the southeast Pacific. ICES J Mas Sci 63: 1338-1345.

Cammen LM. (1980). The significance of microbial carbon in the nutrition of the deposit feeding polychaete Nereis succinea. Mar Biol 61: 9-20.

Chareonpanich C, Montani S, Tsutsumi H, Matsuoka S. (1993). Modification of chemical characteristics of organically enriched sediment by Capitella sp. I. Mar Pollut Bull 26: 375-379.

Collins MD, Jones D. (1981). Distribution of isoprenoid quinines structural types in bacteria and their taxonomic implications. Microbiol Rev 45: 316-354.

Cottrell MT, Kirchman DL. (2000a). Natural assemblages of marine proteobacteria and members of the CytophagaFlavobacter cluster consuming low- and high-molecular-weight dissolved organic matter. Appl Environ Microbiol 66: 1692-1697.

Cottrell MT, Kirchman DL. (2000b). Community composition of marine bacterioplankton determined by $16 \mathrm{~S}$ rRNA gene clone libraries and fluorescence in situ hybridization. Appl Environ Microbiol 66: 5116-5122.

Dang H, Li T, Chen M, Huang G. (2008). Cross-ocean distribution of Rhodobacterales bacteria as primary surface colonizers in temperate coastal marine waters. Appl Environ Microbiol 74: 52-60.

Dang H, Lovell CR. (2000). Bacterial primary colonization and early succession on surfaces in marine waters as determined by amplified rRNA gene restriction analysis and sequence analysis of $16 \mathrm{~S}$ rRNA genes. Appl Environ Microbiol 66: 467-475.

Dobbs FC, Guckert JB. (1988). Microbial food resources of the macrofaunal deposit feeder Ptychodera bahamensis (Hemichordata: Enteropneusta). Mar Ecol Prog Ser 45: 127-136.

Elifantz H, Dittel AI, Cottrell MT, Kirchman DL. (2007). Dissolved organic matter assimilation by heterotrophic bacterial groups in the western Arctic Ocean. Aquat Microb Ecol 50: 39-49.

Elifantz H, Malmstrom RR, Cottrell MT, Kirchman DL. (2005). Assimilation of polysaccharides and glucose by major bacterial groups in the Delaware Estuary. Appl Environ Microbiol 71: 7799-7805.

FAO (1992). Aquaculture production, 1984-1990. FAO Fisheries Circular 815: 206. Rome, Italy.

Fauchald K, Jumars PA. (1979). The diet of worms: a study of polychaete feeding guilds. Oceanogr Mar Biol Ann Rev 17: 193-284.

Findlay S, Tenore K. (1982). Nitrogen source for a detritivore: detritus substrate versus associated microbes. Science 218: 371-373. 
Gooday AJ, Turley CM. (1990). Responses by benthic organisms to inputs of organic material to the ocean floor: a review. Philos T Roy Soc A 331: 119-138.

Gowen RJ, Bradbury NB. (1987). The ecological impact of salmonid farming in coastal waters: a review. Oceanogr Mar Biol Ann Rev 25: 563-575.

Grassle J, Grassle JF. (1976). Sibling species in the marine pollution indicator Capitella (Polychaeta). Science 192: $567-569$.

Grossmann S, Reichardt W. (1991). Impact of Arenicola marina on bacteria in intertidal sediments. Mar Ecol Prog Ser 77: 85-93.

Haines EB, Montague CL. (1979). Food sources of estuary invertebrates analyzes using ${ }^{13} \mathrm{C} /{ }^{12} \mathrm{C}$ ratios. Ecology 60 : $48-56$.

Hargrave BT. (1976). The central role of invertebrate faeces in sediment decomposition. In: Anderson JM, Macfadyen A (eds). The Role of Terrestrial and Aquatic Organisms in Decomposition Processes. Blackwell Press: Oxford, pp 301-321.

Hedrick DB, White DC. (1986). Microbial respiratory quinones in the environment. J Microbiol Methods 5: 243-254.

Hiraishi A. (1999). Isoprenoid quinones as biomarkers of microbial populations in the environment. J Biosci Bioeng 88: 449-460.

Hiraishi A, Iwasaki M, Kawagishi T, Yoshida N, Narihiro T, Kato K. (2003). Significance of lipoquinones as quantitative biomarkers of bacterial populations in the environment. Microbes Environ 18: 89-93.

Hiraishi A, Morishima Y, Takeuchi J. (1991). Numerical analysis of lipoquinone patterns in monitoring bacterial community dynamics in wastewater treatment systems. J Gen Appl Microbiol 37: 57-70.

Holmer M, Kristensen E. (1992). Impact of marine fish cage farming on metabolism and sulphate reduction of under-lying sediments. Mar Ecol Prog Ser 80: 191-201.

Hu H-Y, Lim B-R, Goto N, Fujie K. (2001). Analytical precision and repeatability of respiratory quinones for quantitative study of microbial community structure in environmental samples. J Microbiol Methods 47: 17-24.

Hylleberg J. (1975). Selective feeding by Abarenicola pacifica with notes on Abarenicola vagabunda and a concept of gardening in lugworms. Ophelia 14: 113-137.

James PG, Russell PH. (1996). Phylogenetic analysis of the bacterial communities in marine sediments. Appl Environ Microbiol 62: 4049-4059.

Karakassis I, Hatziyanni E. (2000). Benthic disturbance due to fish farming analyzed under different levels of taxonomic resolution. Mar Ecol Prog Ser 203: 247-253.

Kinoshita K, Tamaki S, Yoshioka M, Srithonguthai S, Kunihiro T, Hama D et al. (2008). Bioremediation of organically enriched sediment deposited below fish farms with artificially mass-cultured colonies of a deposit-feeding polychaete Capitella sp. I. Fish Sci 74: 77-87.

Kunihiro T, Miyazaki T, Kinoshita K, Satou A, Inoue A, Hama D et al. (2005). Microbial community dynamics in organically enriched sediment below fish net pen culture with artificially cultured colonies of the polychaete Capitella sp. I. Bull Soc Sea Water Sci Jpn 59: 343-353 (in Japanese).

Kunihiro T, Miyazaki T, Uramoto Y, Kinoshita K, Inoue A, Tamaki S et al. (2008). The succession of microbial community in the organic rich fish-farm sediment during bioremediation by introducing artificially mass-cultured colonies of a small polychaete, Capitella sp. I. Mar Pollut Bull 57: 68-77.

Levinton JS. (1972). Stability and trophic structure in deposit-feeding and suspension-feeding communities. Am Nat 106: 472-486.

Lopez GR, Levinton JS. (1987). Ecology of deposit-feeding animals in marine sediments. Q Rev Biol 62: 235-260.

Lucas F, Bertru G. (1997). Bacterialysis in the gut of Nereis diversicolor (O.F. Müller) and effect of the diet. J Exp Mar Biol Ecol 215: 235-245.

Lucas FS, Bertrus G, Hofle MG. (2003). Characterization of free-living and attached bacteria in sediments colonized by Hediste diversicolor. Aquat Microb Ecol 32: 165-174.

Macleod CK, Moltschaniwskyj NA, Crawford CM, Forbes SE. (2007). Biological recovery from organic enrichment: some systems cope better than others. Mar Ecol Prog Ser 342: 41-53.

Malmstrom RR, Cottrell MT, Elifantz H, Kirchman DL. (2005). Biomass production and assimilation of dissolved organic matter by SAR11 bacteria in the Northwest Atlantic Ocean. Appl Environ Microbiol 71: 2979-2986.

Marinelli RL, Lovell CR, Wakeham SG, Ringelberg DB, White DC. (2002). Experimental investigation of the control of bacterial community composition in macrofaunal burrows. Mar Ecol Prog Ser 235: 1-13.

Meyer-Reil LA. (1983). Benthic response to sedimentation events during autumn to spring at a shallow water station in the Western Kiel Bight. II. Analysis of benthic bacterial populations. Mar Biol 77: 247-256.

Moran MA, González JM, Kiene RP. (2003). Linking a bacterial taxon to sulfur cycling in the sea: studies of the marine Roseobacter group. Geomicrobiol J 20: 375-388.

Moran MA, Schell MA, González JM, Sun F, Sun S, Binder BJ et al. (2007). Ecological genomics of marine roseobacters. Appl Environ Microbiol 73: 4559-4569.

Muyzer G, Dewaal EC, Uitterlinden AG. (1993). Profiling of complex microbial populations by denaturing gradient gel electrophoresis analysis of polymerase chain reaction-amplified genes coding for $16 \mathrm{~S}$ rRNA. Appl Environ Microbiol 59: 695-700.

Naylor RL, Goldburg RJ, Primavera JH, Kautsky N, Beveridge MCM, Clay J et al. (2000). Effect of aquaculture on world Fish supplies. Nature 405: 1017-1024.

Nogales B, Aguiló-Ferretjans MM, Martín-Cardona C, Lalucat J, Bosch R. (2007). Bacterial diversity, composition and dynamics in and around recreational coastal areas. Environ Microbiol 9: 1913-1929.

Papaspyrou S, Gregersen T, Kristensen E, Christensen B, Cox RP. (2006). Microbial reaction rates and bacterial communities in sediment surrounding burrows of two nereidid polyshaetes (Nereis diversicolor and N. virens). Mar Biol 148: 541-550.

Pearson TH, Rosenberg R. (1978). Macrobenthic succession in relation to organic enrichment and pollution of the marine environment. Oceanogr Mar Biol Ann Rev 16: 229-311.

Perrière G, Gouy M. (1996). WWW-Query: an on-line retrieval system for biological sequence banks. Biochimie 78: 364-369.

Pinhassi J, Azam F, Hemphälä J, Long RA, Martinez J, Zweifel UL et al. (1999). Coupling between bacterioplankton species composition, population dynamics, and organic matter degradation. Aquat Microb Ecol 17: 13-26. 
Plante CJ, Shriver AG. (1998). Differential lysis of sedimentary bacteria by Arenicola marina L: examination of cell wall structure and exopolymeric capsules as correlates. J Exp Mar Biol Ecol 229: 35-52.

Plante CJ, Wilde SB. (2001). Bacterial recolonization of deposit-feeder egesta: in situ regrowth of immigration? Limnol Oceanogr 46: 1171-1181.

Pomeroy LR, Wiebe WJ. (2001). Temperature and substrates as interactive limiting factors for marine heterotrophic bacteria. Aquat Microb Ecol 23: 187-204.

Ratkowsky DA, Olley J, McMeekin TA, Ball A. (1982). Relationship between temperature and growth rate of bacterial cultures. J Bacteriol 149: 1-5.

Reichardt W. (1988). Impact of bioturbation by Arenicola marina on microbiological parameters in intertidal sediments. Mar Ecol Prog Ser 44: 149-158.

Saitou K, Nagasaki K, Yamakawa H, Hu H-Y, Fujie K. (1999). Linear relation between the amount of respiratory quinones and the microbial biomass in soil. Soil Sci Plant Nutr 45: 775-778.

Sanders HL. (1958). Benthic studies in Buzzards Bay: I. Animal-sediment relationships. Limnol Oceanogr 3: 245-258.

Shioi Y. (1986). Growth characteristics and substrate specificity of aerobic photosynthetic bacterium, Erythrobacter sp. (OCh 114). Plant Cell Physiol 27: 567-572.

Srithongouthai S, Endo A, Inoue A, Kinoshita K, Yoshioka M, Sato A et al. (2006). Control of dissolved oxygen levels of the water in the net pens for fish farming with a microscopic bubble generating system. Fish Sci 72: 485-493.

Steward CC, Nold SC, Ringelberg DB, White DC, Lovell CR. (1996). Microbial biomass and community structures in the burrows of bromophenol producing and non-producing marine worms and surrounding sediments. Mar Ecol Prog Ser 133: 149-165.

Thompson JD, Gibson TJ, Plewniak F, Jeanmougin F, Higgins DG. (1997). The ClustalX windows interface: flexible strategies for multiple sequence alignment aided by quality analysis tools. Nucleic Acids Res 25: 4876-4882.

Tsutsumi H. (1987). Population dynamics of Capitella capiteta (Polychaeta; Capitellidae) in an organically polluted cove. Mar Ecol Prog Ser 36: 139-149.

Tsutsumi H. (1990). Population persistence of Capitella sp. (Polychaeta; Capitellidae) on a mud flat subject to environmental disturbance by organic enrichment. Mar Ecol Prog Ser 63: 147-156.

Tsutsumi H. (1995). Impact of fish net pen culture on the benthic environment of a cove in south Japan. Estuar 18: 108-115.

Tsutsumi H, Kikuchi T. (1983). Benthic ecology of a small cove with seasonal oxygen depletion caused by organic pollution. Publ Amakusa Mar Biol Lab 7: 17-40.

Tsutsumi H, Kinoshita K, Srithongouthai S, Sato A, Nagata S, Inoue A et al. (2005a). Treatment of the organically enriched sediment below the fish farm with the biological activities of the artificially masscultured colonies of a small deposit feeding polychaete, Capitella sp. I. Benthos Res 60: 17-24.

Tsutsumi H, Montani S. (1993). Utilization of biological activities of capitellied polychaete for treatment of
'Hedoro' (organically enriched sediment) deposited on the marine bottom below fish net pen culture. Nippon Suisan Gakkaishi 59: 1343-1347 (Japanese).

Tsutsumi H, Montani S, Kobe H. (2002). Bioremediation of organic matter loaded on the sediment in outdoor pools with a polychaete, Capitella sp. 1. Fish Sci 68: 613-616.

Tsutsumi H, Srithongouthai S, Inoue A, Sato A, Hama D. (2006). Seasonal fluctuations in the flux of particulate organic matter discharged from net pens for fish farming. Fish Sci 72: 119-127.

Tsutsumi H, Taniguchi A, Sakamoto N. (2005b). Feeding and burrowing behaviors of a deposit-feeding capitellid polychaete, Capitella sp. I. Benthos Res 60: 51-58.

Tsutsumi H, Wainright S, Montani S, Saga M, Ichihara S, Kogure K. (2001). Exploitation of a chemosynthetic food resource by the polychaete Capitella sp. I. Mar Ecol Prog Ser 216: 119-127.

Urakawa H, Kita-Tsukamoto K, Ohwada K. (1999). Microbial diversity in marine sediments from Sagami Bay and Tokyo Bay, Japan, as determined by $16 \mathrm{~S}$ rRNA gene analysis. Microbiology 145: 3305-3315.

Wada M, Wu S-S, Kogure K, Tsutsumi H. (2005). Shor-term impact of biological activities of a burrowing polychaetes, Capitella sp. I, on bacterial abundance and the chemical characteristics in organically enriched sediment. Benthos Res 60: 59-66.

Wada M, Wu S-S, Tsutsumi H, Tsukamoto K-K, Do H-K, Nomura $\mathrm{H}$ et al. (2006). Visual assessment of the respiring microorganisms associated with burrow structures of Capitella sp. I in seawater soft-agar microcosms. Plankton Benthos Res 1: 54-58.

Wada M, Zhang D, Do H-K, Nishimura M, Tsutsumi H, Kogure K. (2008). Co-inoculation of Capitella sp. I with its synergistic bacteria enhances degradation of organic matter in organically enriched sediment below fish farms. Mar Pollut Bull 57: 86-93.

Weston DP. (1990). Quantitative examination of macrobenthic community changes along an organic enrichment gradient. Mar Ecol Prog Ser 61: 233-244.

WFCC-MIRCEN World Data Centre for Microorganisms (WDCM) database. (1995). Available from <http:// wdcm.nig.ac.jp/wdem/Quinone.html $\rangle$. Final updated on 3 October 1995.

Wu RSS. (1995). The environmental impact of marine fish culture: towards a sustainable future. Mar Pollut Bull 31: 159-166.

Wu SS, Tsutsumi H, Kita-Tsukamoto K, Kogure K, Ohwada K, Wada M. (2003). Visualization of the respiring bacteria in sediments inhabited by Capitella sp. I. Fish Sci 69: 170-175.

Yokokawa T, Nagata T. (2010). Linking bacterial community structures to carbon fluxes in marine environments. J Oceanogr 66: 1-12.

Yokota A, Akagawa-Mathusita M, Hiraishi A, Katayama Y, Urakami T, Yamasato K. (1992). Distribution of quinone systems in microorganisms: Gram-negative eubacteria. Bull JFCC 8: 136-171.

Zola H. (1967). Sugar phosphate polymers in polychaete tubes and in mineralized animal tissues. Comp Biochem Physiol 21: 179-183. 